\title{
Interstitium: The Ideological Domination of America
}

\author{
Dwight D. Murphey
}

All through my adult life the content of "respectable" opinion has been determined by whatever narrative comes out of the various organs of advancing leftist opinion. This narrative is instantly conformed to by the millions of people who instinctively want to stand among the others to share what is thought indisputably to be right opinion. When I call this ubiquitous Establishment of leftist opinion "the Interstitium," I am applying an analogy to a recent advance in medical research, which has found a fluid-filled matrix through much of the human body, denominated by an "Interstitium," amounting, in the opinion of some, to a distinct organ. If we think of a societal Interstitium rather than a bodily one, we see an all-pervasive matrix in the United States, and indeed throughout the West that consists of an interwoven structure of ideologically infected "respectable" opinion. This matrix demands ideological conformity and pulsates within an immense swath of institutions-the media, most recently Big Tech, the entertainment industry, academia, the professions, the major political parties, the corporate culture, and in fact within the great majority of people who have passed through the universities of the past century. Over the years, I have written extensively about the "alienation of the intellectual" as being a crucial element in American history, and especially in the evolution of leftist ideology. In light of its success in fashioning the Interstitium, we should see it as a major component of the matrix, in fact, part of its DNA.

This particular cultural matrix is different from the consensus among cultivated people that is a healthy, even vital, feature of a society. Ours is a matrix infected with an ideology fashioned by a two-century drumbeat of disaffection.

When Hillary Clinton denounced "the deplorables," she made express a division within the American people that goes back many years. (See Sinclair Lewis's 1922 novel Babbitt that famously presents the intellectual culture's

Dwight D. Murphey, of Hermitage, Tennessee (dwightmurphey@sbcglobal.net), recently published an essay, "The America l've Loved," to his collected writings website (dwightdmurphey.com), and would like to share a passage that introduces a concept that should be useful in helping grasp the extreme breadth of the ideological domination America experiences today. 
caricature of the fictional George Babbitt as a mediocre middle-class businessman.) Its attitudes molded by the alienation, the Interstitium holds in contempt the millions of "deplorables" who live separately from it. This is a population that makes up the majority of the native American population. It contains a great many intelligent, talented, even highly educated people, but they lack the cohesiveness that glues the "politically-correct" ideology together. In the art world, say, there are many excellent artists throughout the United States, but it is not their work that is honored by the cognoscenti who dominate the official art community. (Go to the New Mexico state art gallery in Santa Fe, for example. New Mexico is a state that attracts many fine artists, but the state art gallery is, not surprisingly, dominated by meaningless junk.) The millions of people in the American majority are not inert; their work, talents, and energies make up the bulk of life. But their submergence under an opinion-dictating Interstitium is what allows that ideological control to govern.

As we have come to see in the context of "cancel culture," a ubiquitous cartel of official opinion within the context of what can now only be described as a psychotic ideology has totalitarian potential. It is a mistake to think of government, especially if expanded to socialism, as the only threat to individual liberty. The Interstitium, acting in concert as it does, has powers of domination and control that rival the coercive power of the state. 